\title{
Effect of Tax Policy on Economic Growth in Nigria (1994-2013)
}

\author{
Nwadialor Eugene ${ }^{1} \&$ Ekezie Chineze Abigail ${ }^{1}$ \\ ${ }^{1}$ Department of Accountancy, Anambra State University, Igbariam Campus, Anambra State, Nigeria \\ Correspondence: Ekezie Chineze Abigail, Department of Accountancy, Anambra State University, Igbariam Campus, \\ Anambra State, Nigeria.
}

Received: December 2, 2015

Accepted: December 29, 2015

Online Published: January 13, 2016

doi:10.5430/ijba.v7n1p50

URL: http://dx.doi.org/10.5430/ijba.v7n1p50

\begin{abstract}
This study examined the effect of tax policy on Economic Growth in Nigeria. The study uses annual time serial data of 20 years (1994-2013) collected from the published report of the FIRS of various years, OLS regression analysis was use to investigate the relationship that exist between the dependent and independent variables. The findings revealed that tax have a significant effect on the Economic growth in Nigeria. It showed that the proportion of indirect to total tax have increased over the years. The study therefore recommends among others that the Government tax policy should shift more to indirect tax due to the expansionary and non-distortionary nature.
\end{abstract}

Keywords: tax base, tax rate, tax administration and tax productivity

\section{Introduction}

The economic growth of any nation depends on the amount of resources generated and under its control to finance its infrastructural need and meet its day to day expenditure. The resources needed is believed however to be generated from external and internal- through a structured tax system. Tax as a macro-economic policy tool determines the level and pace of economic growth in nations of the world (Omojemite and Godwin 2012). A well-structured tax system offer government opportunity to generate needed revenue to meet its ever growing need. Tax is a veritable and sustainable source of revenue for government and a tool for fiscal policy and macro-economic management. It is a potential tool for economic and social reform as it pervades all aspect of the economy, individual, companies, citizens and foreigners. As a macroeconomic tool, Marshal (1992) likens its efficacy to power to destroy. The tax system is lopsided and dominated by oil revenue which poses formidable challenges to the establishment of effective and efficient tax system (Odusola, 2006). Odusola, identifies some of the challenges facing the Nigeria tax system which includes-paucity of data, non-availability of tax statistics, poor administration, multiplicity of tax, structural problem and non-prioritization of tax effort.

Nigeria operates a federal system of government with three arms and three tiers of government; the federal, the state and the local government each receiving monthly allocation from the federation account (pooled revenue) generated mostly from tax. Nigeria tax system comprises of direct and indirect taxes. The tax administration and jurisdiction in Nigeria is structured in line with the government fiscal power. There are tax exclusively for the federal government, some are shared between the federal and state; some taxes are within the jurisdictions of the state while others for the local government.

Nigeria operates a cash budget system where expenditure proposal are anchored on projected revenue. To meet this projected revenue, Governments have three options to borrow, to tax or both. Using tax, governments try determines the optimal tax rate for a given level of expenditure. Musgrave (1959) observes that economic development brings about increase in demand for public expenditure and the increase must be matched by in a greater extent with supply in taxing capacity. Since tax is the major source of Government revenue in Nigeria to meet its expenditure on one hand and the myriad problem facing the tax system a proactive mind may ask- to what extent can the tax system generate the needed revenue to meet up with this ever increasing government expenditure burden i.e. How productive is the tax system (efficient and effective in providing the needed revenue). Odusola (2006) observed that government revenue at any given point in time is influenced by the changes in tax policies, tax rate, tax base and tax incentives. 


\subsection{Statement of the Problem}

Ifurueze and Odesa (2014) observed that government expenditure has been on increased since the early $70 \mathrm{~s}$, the increment as they observed mirror the oil and tax revenue increase since tax is the major source of government revenue in Nigeria to meet its expenditure on one hand and the myriad problem facing the Nigeria tax a proactive mind may ask to what extent can be tax system generate the needed revenue to meet up with this ever increasing government expenditure burden i.e. How productive is the tax system (efficient and effective in providing the needed revenue). Odusola (2006) observed that government revenue desire any given point in time is influence by the changes in tax policies, domestic savings, investments, consumption and expenditure. The measurement of how productive a tax system is done through study of tax buoyancy and tax elasticity. The studies on the productivity of the Nigeria tax system are few limited in scope, coverage and method of analysis and findings for instance adopted. Omoruyi, (1983) Ifuruez and Odesa (2014) and Iboma (2012). Study on the productivity of the Nigeria tax system. Omoruyi (1983) study covered the period of 1960-1979; Ariyo (1997) updated the study by covering a longer period of 1960 -1990 while Omojimite and Iboma (2012) study cover the period of $1994-2013$. Recent studies have turned to investigate the effort of tax policy on economic growth variables, for instance, Arnold (2008), Arnold, and Vartia (2009), all conducted in Europe found negative relationship between income taxes and economic growth. Other studies, for instance Mashkoor, Yahya and Ali (2010), Arisony and Unlukaplan (2010) all in Pakistan and turkey respectively, found no significant relationship between income taxes and economic growth. Among the studies carried out in Nigeria, Ogbonna and Ebimobowei (2012), Umoruand and Anyiwe (2013), and Mgbame (2012) found a positive relationship between tax Reforms and Economic Growth. Ekeocha, Malolu and Onyema (2012), suggested a shift from direct to indirect taxation, while llaboya and Mgbame (2012), found negative relationship between consumption (indirect) tax and economic growth and recommended a review of the current position of Nigeria tax policy on a shift from direct and indirect taxation. Those studies also differ in methodology and scope in their findings. The results from these studies are mixed and hence, hard to draw policy prescription from.

\subsection{Objective of the Study}

The general objective of this study is to evaluate the impact of tax policy on economic growth of Nigeria. The objectives include:

1. Ascertain the relationship between tax policy and economic growth in Nigeria.

2. Examine the relationship between direct tax revenue and economic growth of Nigeria.

3. Determine the impact of indirect tax policy and economic growth of Nigeria.

\subsection{Statement of Hypothesis}

$\mathrm{Ho}^{1}$ : There is no significant relationship between tax policy and economic growth of Nigeria.

$\mathrm{Ho}^{2}$ : There is no significant relationship between direct tax policy and economic growth of Nigeria.

$\mathrm{Ho}^{3}$ : There is no significant relationship between indirect tax and economic growth of Nigeria.

\subsection{Significance of Study}

Nigeria as a nation stands to gain from an improved tax policy which enhances economic growth and development, equitable distribution of income greater employment. This will no doubt go a long way in addressing the issue of crime and violence and other social vices in the country.

This study therefore will help to provide the necessary policy guide for government on the effect of different types of tax policy. The research findings would be of importance to policy makers at national level as the design policies aimed at enhancing tax revenue collection, tax administration, block tax loopholes and ensure economic growth through a better taxation system. Multinational and companies in Nigeria wishing to invest in Nigeria would find this study useful. Tax practitioners and other relevant bodies and those who wish to undertake further research on taxation will also find the literature arising from this study to be great value

This study was country specific and will seek to examine the productivity of the tax system by the use of tax buoyancy and tax elasticity. The evidence presented in this research is based on a fairly standard empirical model of the relationship between economic growth and tax system derived from the Musgrave tax theory. It used annual time series data from 1994 to 2013. Among the constraints faced by the study are; the dearth of accurate secondary data, time and other resources needed for the execution of a work of this nature.

However efforts were made to ensure that correct data was gathered and adequate provision were made for errors so that the authenticity and credibility of the findings are not affected. 


\section{Review of Related Literature}

The economic history of both developed and developing countries reveals that taxation is an important weapon or instrument in the hand of government, not only to generate revenue, but also to achieve fiscal goals that influence the direction of investment and taming the consumption and production of certain goods and services, Akujiobi and Ebimobiwei (2012).

\subsection{Conceptual Framework}

A good tax system as a macro-economic policy tool have a direct impact on economic growth of a nation given it various effects on savings, investment, labour and research and the possible substitution between these factors. Thingan (1995) believed that tax is the most potent economic tool which facilitates reduction of private consumption, increase investment, resource allocation and transfer to government resources for economic growth is also a tool for expansion and contraction of an economy.

\subsubsection{Direct and Indirect Tax}

A direct tax is one levied directly on the person who is intended to pay the tax, whereas an indirect tax is borne by a person other than the one from whom the tax is collected. This classification can prove to be misleading at times, as the incidence of some direct taxes, for example, Company tax, can easily be shifted. Examples of direct taxes are: Income Tax, Company Tax, Capital Gains Tax, Education Tax, Petroleum Profit Tax.

Whereas, examples of indirect taxes are: (a) Value Added Tax (b) Custom and Excise Duties.

\subsubsection{Direct Tax and Economic Growth in Nigeria}

Direct taxes in Nigeria include the Personal Income Taxes (PIT), Company Income Tax (CIT), the Petroleum Profit Tax (PPT) and Education Tax. Eugene and skinner (1996) believe that taxation can effect economic growth in major five ways. First, higher taxes can discourage the investment rate through high statutory taxes rates on corporate and individual income, high effective capital gains taxes and low depreciation allowances. Secondly, taxes discourage labour force participation or distort occupational choices and also affect the choice for acquisition of skills, education and training third, tax policy has the potential to discourage productive growth by attempting to tax research and development and the development of ventures capital. Fourth, tax policy can influence the marginal productivity of capital by channeling investment from heavily tax sectors to more highly taxed sector with lower overall productivity. Fifth, heavy taxation on labour supply can distort the efficient use of human capital by discouraging worker from employment in sectors with high social productivity but a heavy tax burden. Taxation of personal income: taxation of personal labour may influence economic growth by affecting human capital investment, through supply of labour and work effort. Flat incomes do not influence education decision as the government equally in the forgone earnings and the future return education (Troset 1993). Indenture and compensation policies matter for individuals effort (Ehrenbery 1990 and Prendergast 1996).

\subsubsection{Indirect Taxation and Economic Growth}

Indirect taxes are also called taxes on consumption expenditure it is usually on that rate or regressive as the same tax paid by everybody. Indirect taxes in Nigeria include: The value added tax (VAT) custom duty e.t.c it is easier to collect and less prone to evasion.

The Nigeria taxes system has since shifted more towards indirect taxation as the alternative to direct taxation which is often more difficult and more costly to collect, prone to high rate of tax and tax avoidance.

Theory suggest that the different impact of some of the major indirect taxes such as those on consumption, is fairly limited at least as regards long-run economic performance: these taxes are relatively neutral with respect to savings and investment decisions, they do not discriminate between imports and domestically produced goods and provide for a symmetric treatment of labour and capital income. Hence from the point of view of economic efficiency, a tax system with a relatively low level of direct taxation and a larger share of indirect taxes may home certain advantages. Ariyo (1999) contend that distortionary taxation (taxes) on income reduces that rate of economic growth and that non-discretionary taxation (indirect taxes) does not.

\subsubsection{Structure of Nigeria Tax System}

Nigerian tax system is concentrated on petroleum and trade taxes while direct and broad-based indirect taxes like the value-added (VAT) are neglected. This is a structural problem for the country tax system. Although direct taxes and VAT have the potential for expansion, their impact is limited because of the dominance of the informal sector in the country. Furthermore, the limited formal sector is supported with strong unions that act as pressure groups to deter 
any appreciable tax increment from gross income. Fourth, the widening fiscal deficit that over the years has threatened macroeconomic stability and prospects for economic growth makes the prospect of tax reform very appealing. VAT have the potential for expansion, their impact is limited because of the dominance of the informal sector in the country. Furthermore, the limited formal sector is supported with strong unions that act as pressure groups to deter any appreciable tax increment from gross income. Fourth, the widening fiscal deficit that over the years has threatened macroeconomic stability and prospects for economic growth makes the prospect of tax reform very appealing.

\subsubsection{Tax Policy Reforms and Institutional Development in Nigeria}

The need to address the problem of low tax returns motivated the Federal government to embark on a number of reforms to existing tax laws. According to Ocran (2009), the objectives of tax reforms in Nigeria include: to bridge the gap between the national development needs and the funding of the needs; to ensure taxation, as a fiscal policy instrument, in achieving improved infrastructure and public service delivery to the public; to improve on the level of tax derivable from non-oil activities, vis-à-vis revenue from oil activities; efforts at constantly reviewing the tax laws to reduce/manage tax evasion and avoidance; and to improve the tax administration to make it more responsive, reliable, skillful and taxpayers friendly and to achieve other fiscal objectives. The Nigerian tax system has experienced series of reforms since 1904 to date. The effects of the various reforms in the country are as follows:

1. The introduction of income tax in Nigeria between 1904 and 1926.

2. The grant of autonomy to the Nigerian Inland Revenue in 1945.

4. The formation of the Inland Revenue Board in 1958.

5. The promulgation of the Petroleum Profit Tax Ordinance No. 15 of 1959.

6. The promulgation of Income Tax Management Act 1961.

7. The establishment of the Lagos State Inland Revenue Department.

8. The promulgation of the Companies Income Tax Act (CITA) 1979.

9. The establishment of the Federal Board of Inland Revenue under CITA 1979.

10. The establishment of the Federal Inland Revenue Service between 1991 and 1992.

11. The tax policy and administration reforms amendment 2001 and 2004.

Below is the list of taxes and their jurisdiction.

Table 1. Nigeria major taxes

\begin{tabular}{lll}
\hline Types of tax & Jurisdiction & Adm. / collection \\
\hline 1. Import duties & Federal & Federal \\
\hline 2. Excise duties & Federal & Federal \\
\hline 3. Export duties & Federal & Federal \\
\hline 4. Mining rents and royalties & Federal & Federal \\
\hline 5. Petroleum profit tax Federal & Federal & Federal \\
\hline 6. Companies income tax & Federal & Federal \\
\hline 7. PIT: Armed forces, external affairs officers and FCT & Federal & Federal \\
\hline 8. Capital gains tax & Federal & States \\
\hline 9. Personal income tax & Federal & States \\
\hline 10. television \&wireless radio license & Federal & States \\
\hline 11. Stamp duties & Federal & States \\
\hline 12. Estate duties & Federal & States \\
\hline 13. Gift tax & Federal & States \\
\hline 14. Sales or purchase tax & Federal & States \\
\hline 15. Football and other betting taxes & States & States \\
\hline
\end{tabular}




\begin{tabular}{lll}
\hline 16.Vehicle reg. \& driver's license fee & States & States \\
\hline 17. Entertainment tax & States & States \\
\hline 18. Land registration and survey fees & States & States \\
\hline 19. Property tax & States & Local Govt. \\
\hline 20. Market and trading license fees & States & Local Govt.
\end{tabular}

Source: Phillips (1991) as cited by Ariyo (1997)

\subsection{Theoretical Exposition}

The Laffer Curve was developed in 1979 by Arthur Laffer. According to the theory, changes in tax rates affect Government revenue in two ways. One is immediate, which theory describes as "arithmetic." Under this, every dollar in tax cuts translates directly to one less dollar in government revenue. The other effect is longer-term in nature, which Laffer describes as the "economic" effect. This works in the opposite direction. Lower tax rates put more money into the hands of taxpayers, who then spend it. This creates more business activity to meet consumer demand. Next, companies hire more workers, who spend their additional income. This boost to economic growth generates a larger tax base, which eventually makes up for the initial revenue lost from the tax cut.

The Curve shows that, zero taxes will results in no government revenue and, thus, no government. Of course, increasing taxes from zero immediately boosts government revenue. In the beginning, raising taxes still does a good job of increasing total revenue. As the government keeps raising taxes, the payoff in additional revenue becomes less, and the curve steepens.

At some point, additional taxes really start to become a burden on economic growth. Demand is inhibited so much that the long-term decline in the tax base more than offsets the immediate increase in tax revenue. Beyond this point, additional taxes actually result in reduced government revenue. When tax rates are $100 \%$, then government revenue is zero. If the government takes all personal income and business profit, then no one works or produces goods, so the tax base disappears.

Various efforts have been made to quantify the relationship between tax revenue and tax rates. While the interaction between tax rates and tax revenue is generally accepted, the precise nature of this interaction is debated. In practice, the shape of a hypothetical Laffer curve for a given economy can only be estimated. The relationship between tax rate and tax revenue is likely to vary from one economy to another and depends on the elasticity of supply for labor and various other factors. Even in the same economy, the characteristics of the curve could vary over time. Complexities such as progressive tax and possible differences in the incentive to work for different income groups complicate the task of estimation. The structure of the curve may also be changed by policy decisions.

\subsection{Review of the Empirical Literature}

Alongside the theoretical modeling of optimal taxation and the empirical literature on the determinants of tax effort, a separate base of literature has developed over the past several decades examining the impact of reliance on different tax instruments for different aspects of economic activity, including economic growth. Generally speaking, these empirical studies have found significant results for the effects of different tax policy on growth. An earlier set of papers, including Atkinson and Stern (1980).

Ifurueze and Odesa (2013) find evidence that greater reliance on indirect taxation, as opposed to direct taxation, has significant positive effects on economic growth. Along similar lines, Kneller, Bleaney, and Gemmell (1999) suggest that in OECD countries, while income taxes reduce growth, consumption taxes do not. For the same group of countries, Wildman (2001) find similar evidence for personal income taxation, especially with higher progressivity, measured in terms of the long-run income elasticity of tax revenues. Wildman suggests that personal income tax progressivity affects growth not so much through accumulation of physical capital as through accumulation of human capital.

Omojimite and Iboma (2012) findings shows a positive relationship between fiscal deficit and inflation and a negative relationship between private investment and national income.

Baily (1980) Feldstein (1980) Landau (1983) their studies find a negative relationship between fiscal deficit financing and economic growth. The differences in opinion on the effect of fiscal deficit financing on the Nigeria economy arise from the mode of financing, Nature, scope and objective. 


\section{Research Design}

This work will be quantitative research predicated on ex-post facto research design. Ex-post facto design was used because of the nature and types of data. Variable on economic performance, tax collections which are normally publish in Federal Government and Central Bank of Nigeria official report. Thus, this research has to adopt them and rely on such official publications for valid and reliable academic exercise.

The data for the various taxes will be extracted from the Federal Inland Revenue service annual report data on economic growth will extracted from the CBN statistical bulletin while the data on value of finish and important goods will be collected from the ministry commerce and chamber and the Nigeria customer report respectively.

\subsection{Model Specification and Decomposition}

The model for this study is premised on the main objective of study and anchored on the sub-objectives. Tax and Economic growth in Nigeria, the buoyancy of the individual taxes is decomposed into the product of the buoyancy of the tax to its base, the buoyancy of the base to income and the buoyancy of the income to economic growth (GDP). The productivity model in this study will be the same as that of kusi (1998). Tax buoyancy is adopted as against elasticity in the decomposition process of tax to base and base to income. This method will eliminate the elasticity approach used by Ariyo (1993) Omojimite and Iboma (2012) which require the isolation of the impact of discretionary which is in line with that of Dickson and Presely (2013) have been identified as effecting tax buoyancy and tax elasticity. However, the main variable used for this work includes.

GDP $=$ Gross Domestic product

TTR $=$ Total tax Ravenous

Dir $\mathrm{T}=$ Direct Tax

Ind. $\mathrm{T}=$ Indirect Tax

RGDP $=$ Real Gross Domestic Product

This can be express mathematically as follows:

$$
\begin{gathered}
\mathrm{GDP}=\mathrm{f}(\mathrm{TTR}, \mathrm{P} \text { Ind. } \mathrm{T}, \text { Dir. T) } \\
\mathrm{TTR}=\mathrm{f}(\text { FDI, RGDP })
\end{gathered}
$$

The time series regression equation will be

$$
\begin{gathered}
\mathrm{GDP}_{\mathrm{t}}=\beta_{0}+\beta{ }_{1} \mathrm{TTR}_{\mathrm{t}}++\beta{ }_{2} \mathrm{IND}_{\mathrm{N}}+\mathrm{T}_{\mathrm{t}}+{ }_{3} \mathrm{DIR} \mathrm{T}_{\mathrm{t}}+\mu \\
\mathrm{RGDP}_{\mathrm{t}}=\beta_{0}+\beta_{1} \mathrm{TTR}_{\mathrm{t}}+\mu \\
\mathrm{FDI}_{\mathrm{t}}=\beta_{0}+\beta_{1} \mathrm{TTR}_{\mathrm{t}}+\mu
\end{gathered}
$$

However, to assess the effect of the individual variable used in this study the following basis ten equation models will be estimated. Based on those models the following regression equations will be analyzed. All the data will be reducing to the same unit using logarithm base ten $\left(\log _{0}\right)$.

$\beta_{0}=$ Constant autonomous terms

$1=$ Coefficient of Buoyancy

$\mu=$ Stochastic Error terms.

\section{Data Presentation and Analysis}

This section discusses the result of the model estimation conducted. The data were subjected to a buoyancy test to determine the leading or lagging tax revenue with respect to their contribution to total tax revenue collected.

Table 2. Estimates of tax policy $(1994-2013)$

\begin{tabular}{llllll}
\hline & SS & MS & R.sq(adj) & D.W & P-value. \\
\hline Petroleum Profit Tax & .73 & 0.1455 & .76 & 1.52 & 0.000 \\
\hline Company Income Tax & 1.13 & 2.3422 & .98 & .92 & 0.000 \\
\hline Customs \& Excise Duties & .73 & 1.5678 & .91 & .52 & 0.000 \\
\hline Value Added Tax & 1.85 & 3.2323 & .61 & 1.20 & 0.000 \\
\hline Total Tax Revenue & .80 & 0.6732 & .95 & 1.41 & 0.000 \\
\hline
\end{tabular}


Table 3. Regression analysis of dependent and independent variables

\begin{tabular}{llllll}
\hline & SS & MS & R.sq(adj) & D.W & p-value. \\
\hline Total tax revenue & .34 & 4.2311 & .61 & 1.03 & 0.000 \\
\hline Total indirect tax & .65 & 0.2343 & .93 & .67 & 0.000 \\
\hline Total Direct tax & .55 & 2.9878 & .86 & .53 & 0.000 \\
\hline RGDP & .88 & .13276 & .72 & 1.22 & 0.000 \\
\hline
\end{tabular}

Table 4. Analysis of variance

\begin{tabular}{llllll}
\hline & DF & SS & MS & F-value & P-value \\
\hline Regression & 1 & 0.364 & 0.364 & 1.791 & 0.197 \\
\hline Residual & 3 & 3.859 & 0.203 & & \\
\hline Total & 4 & 4.223 & 0.211 & & \\
\hline
\end{tabular}

Table 5. Estimate of total tax revenue

\begin{tabular}{lllll}
\hline & SS & R.sq (adj) & D.W & P-value. \\
\hline DIR T & 1.66 & .71 & 1.75 & 0.000 \\
\hline IND. T & .99 & .76 & 1.75 & 0.000 \\
\hline RGDP & .82 & .99 & 1.75 & 0.000 \\
\hline
\end{tabular}

The results of the general regression model revealed that for the period under study, all the explanatory variable adequately explain the pattern of behavior of each dependent variable. Durbin Watson (DW) statistics show that there is a positive autocorrelation.

From Table 2, the coefficient of all the equations result, of all the equations results regarding individual tax sources were all significant at 95 level $\mathrm{R}$ - sq(adj) are high. The result showed that direct and indirect tax has a significant effect on GDP. Showed a weak relationship exist between TTR and GDP as they are less than unity. This result is akin to the one obtained by Ariyo (1997), Dickson and Presley (2013). Value Added Tax and company income tax exhibited a buoyancy excess of unity (1.85 and 1.13 respectively).

Result in Table 3 reveals that all have a significant relationship with their respective tax base (GDP). This is contrary to the result reported in Table 2; only one tax base has a buoyancy exceeding unity. Dickson and Presley (2013) attribute these shortcomings to high rate of tax evasion, misguided tax exemptions and corruption in the administration of the tax system.

\section{Summary of Findings}

This study investigated the effect of tax policy on economic growth of Nigeria from $1994-2013$. The Nigeria tax system is made up of direct and indirect tax. Three models were formulated for the study and regression was run on the time serial data at all levels. The study takes cognizance of the lagged nature of some of the direct tax (PPT and CIT).

During the period under study, no major economic policy was introduced or changed, though some tax rate and rule changes in accordance with macroeconomic goals set out in the budget annually. The result revealed a week relationship between direct tax and Economic Growth. This finding agrees with other studies like Dickson and Presley (2013).

Finding of the effect of VAT on economic Growth is in line with earlier studies by Omojimite and Godwin (2012), Dickson and Presley (2013). The improvement in the effect of some of the tax (PPT, CED, CIT) within the period under study may be attributable to the implementation of the 1992 study group recommendation on efficient tax administration and various efforts to block existing loopholes in the tax system. The effect of indirect tax on economic growth result is quite different from the result of previous studies especially that of Omojimite and Godwin (2012), Dickson and Presley (2013) due to the period of coverage, estimation approach and probably dearth 
of data. The improvement on the effect level can be sustain by adoption of sound policy that will reduce the tax administration inefficiency, block loopholes, tax evasion and eliminate corruption within the tax system.

\subsection{Conclusion}

The findings shows that tax policy have significant effect on economic growth. The various component have different effect on economic growth, the result showed that indirect tax have a strong positive significant relationship with the level of economic growth in Nigeria within the period under review. Direct tax analysis result showed a weak relationship between economic growth and direct tax policy (CIT, PPT). The study thus conclude that it is important for Government to strengthen the indirect tax and shift more to indirect tax as it offer more growth prospect and less cost and administration challenges.

\subsection{Recommendation}

The study recommends as follows:

- That the government should improve the tax administrative system so as to block possible tax evasion by appropriate by policing of exports and import.

- Lowering the company income tax rate further to encourage more investment to broaden the tax base and promote economic growth.

- Government should broaden the tax base by providing the basic infrastructure and enabling environment for private enterprise to strive.

Prudent management and productive utilization of public fund should be encouraged.

\section{References}

Arisoy, I., \& Unlukaplan, C. (2010). Tax Composition and Growth in Turkey: an empirical analysis. International Research Journal of Finance and Economies Issue, 59, 50-61.

Ariyo, A. (1997). Productivity of the Nigeria Tax System: 1970-1990. AERC Research paper 67 African Economic Research Consortium, Nairobi Kenya.

Azubike, O. (2007). Tax and economic growth in Nigeria Time series analysis.

Barro, R., \& Martins, X. (1992). Public Finance in Models of economic Growth. Review of economic studies, 55, 645-661.

Butter, W. (1983). The theory of optimum deficits and debt. NBER working Paper No 1232. Draft Document on the National Tax Policy, updated as at June $7^{\text {th }} 2008$.

Chigbu, E., Akujiobi, L., \& Ebimobiwei, A. (2012). An empirical Study on the causality between Economic Growth and Taxation in Nigeria. Current research journal of Economic Theory, 4(2), 29-38.

Dickson and Presley. (2013). Tax incentives and revenue productivity of the Nigerian tax system. International Journal of Development and Economic Sustainability, 1(1), 33-44.

Ekeocha, P., Malolu, C., \& Onyema, O. (2012). Revenue implication of Nigeria tax system. Journal of Economic and Sustainable Development, 3(8), 206-214.

Feldstein, M., \& Feenberg, D. (1980). The Effect of increased tax rates on taxable income and economic efficiency: a preliminary analysis of the 1993 Tax Rate increases. National Bureau of Economic Research (NBER), working paper 5370 .

Haughton, J. (1998). Estimating tax buoyancy, elasticity and stability. Eager/PSGE- Excise project, methodological Note 1 .

Ifuruez, M., \& Odesa, J. (2014). Productivity of the Nigeria tax system (1994-2013). Journal of management and finance, 3(2).

Ijwere, A. (1991). The overviews of the Nigerian tax system 1960-1989.

Johnson, A., Arnold, J., \& Vartia, L. (2009). Taxation and economic growth. OECD development. economic department working paper no 620.

Mashkoor, M., Yahya, S., \& Ali, A. (2010). Tax revenue and economic growth: an empirical analysis for Pakistan. World Applied Journal, 10(11), 1283-1289. 
Musgrave, R. A. (1959). Public Finance in theory and Practice. Tokyo: McGraw Hill International Book Company, p.64.

Odusola, A. (2003). Internally generated revenue at the local government: issues and challenges. Paper presented at the workshop on Revenue Generations at the state level in Ibadan University.

Olatnji, O. (2013). Value added tax and inflation in Nigeria (1990-2003). Asian journal of Humanities and social science, 1(1), 123-133.

Omojemite, U., \& Godwin, I. (2012, April). Fiscal deficit and the productivity of the Nigeria tax system 1970-2010. Journal of sustainable development, 5(4).

Omoruyi, J. (1983). Growth and flexibility of Federal Government tax revenue 1960-1999. Economic and Financial Revenue CBN, 21(1).

Osoro, N. (1991). Revenue productivity implication of tax reform in Tanzania. AERC research paper 20 Nairobi PP24.

Thingan, I. (1995). Economic growth and tax composition: an analysis of tax changes in OECD. Applied Economics, 37, 2251-2263.

Thompton, D. L. (1990). Do Government Deficits Matter? A review. The Federal Reserve Bank of St. Louis, 72(5), 25-39.

Umoru, D., \& Anyiwe, M. (2013). Tax structure and economic growth in Nigeria: disaggregated empirical evidence. Research Journal of Finance and Accounting, 4(2), 65-81. 